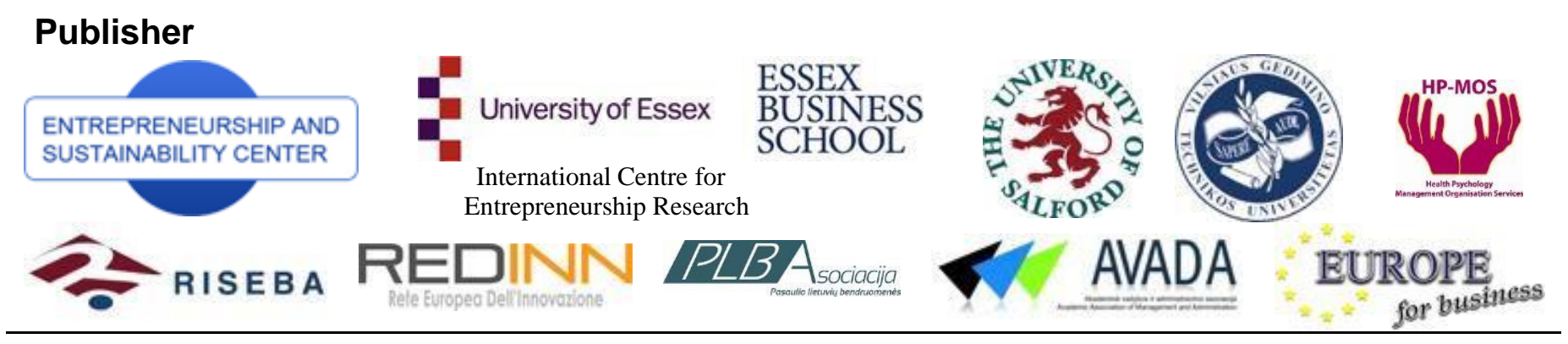

ENTREPRENEURSHIP AND SUSTAINABILITY ISSUES

ISSN 2345-0282 (online) http://jssidoi.org/jesi/aims-and-scope-of-research/

\title{
CrossMark
}

Valid version

\section{CREATIVITY AND INNOVATION MANAGEMENT: TEAM PERFORMANCE PECULIARITIES}

\author{
Vytaute Dlugoborskytè ${ }^{1}$, Vaiva Norvilaité2 ${ }^{2}$ Monika Petraitė ${ }^{3}$ \\ Kaunas University of Technology, K. Donelaicio str. 73, LT-44029 Kaunas, Lithuania \\ E-mail: ${ }^{1}$ vytaute.dlugoborskyte@ktu.edu; ${ }^{2}$ vaiva.norvilaite@ktu.edu; ${ }^{3}$ monika.petraite@ktu.lt
}

Received 30 June 2015; accepted 25 July 2015

\begin{abstract}
In the field of creativity and innovation management much research has gone into individual creativity and effectiveness, and models of innovation management. In corporate innovation, R\&D and product development tools are created and help firms manage innovation projects. Creative behavior is either internally predicated (by personality) or externally induced (by setting conducive contexts). At the team level, most research and managerial practice focuses on establishing the context. The role of certain individuals and their relationship with project success has been described, as has the structure of the team to facilitate certain types of innovation. Thus the aim of this paper is to provide conceptual framework for analyzing the performance of creative innovation teams. Key personality and team role tools are disclosed, performance indicators measuring outputs are identified. Empirical research based on the conceptual framework is conducted on the creative innovation students' teams and the resulting data on their performance is analyzed. Such analytic approach enables to disclose and investigate the behavior and outputs of creative innovation teams.
\end{abstract}

Keywords: Creative innovation team, team performance management, team composition, MBTI, Belbin team roles

Reference to this paper should be made as follows: Dlugoborskytė, V.; Norvilaite, V.; Petraitè, M. 2015. Creativity and innovation management: team performance peculiarities, Entrepreneurship and Sustainability Issues 3(1): 25-39. DOI:

http://dx.doi.org/10.9770/jesi.2015.3.1(2)T

JEL Classifications: O31, M12, L20

\section{Introduction}

Katzenbach and Smith (1993) underlined that "teams will become the primary unit of performance in highperformance organisations". A critical determinant of team performance is the quality of the human resources which make up the team. For this reason the mix of individuals in a team has become an important issue for management development professionals, even though the psychology of individuals is a complex enough subject 
(Partington \& Harris 1999). As the world of companies now turns around the innovation process and ability to innovate, a lot of attention is dedicated to innovation management, as well as, innovation management in teams. Much research has gone to this field, firstly, trying to understand the nature of innovation, and later on - in order to control it. These investigations enclosed the stages of innovation, revealing it to be non linear process, and stressed its' close linkages with creativity. Amabile (1996) provided simple and yet significant definitions of all, innovation, creativity and their connection, stating that creativity is the production of novel and useful ideas in any domain, while innovation is the successful implementation of creative ideas within organization. According to her, creativity by individuals and teams is a starting point for innovation.

Based on the importance of creativity to innovation, extensive research has studied factors enhancing creativity within organizations - creativity models were developed (Amabile et al. 2005; Ford 1996; Borghini 2005; Woodman \& Schoenfeldt 1989) and studied, much attention was devoted to individual and group creativity (Klijn \& Tomic 2010). Descriptions of creative personality during all of these years were refined and most of them now include attributes relevant to idea generation as well as idea implementation (Mathisen et al. 2008). Team creativity is defined in the extent to which teams develop ideas about products, processes, or procedures that are both, novel and potentially useful (Amabile 1996; West 2002). Creativity was found to be most evident in the early stages of innovation processes or cycles, when those in teams are required to develop or offer ideas in response to a perceived need for innovation (West 2002).

Thus a dominant way of thinking about teams with respect to their capacity for creativity and innovation usually seems to be input-process-output models, in which variety of inputs combine to affect intra-group processes and, in turn, influence team outputs (Mathisen et al. 2008). Most studies have been focusing on the input parameters as a context that surrounds a team or diversity of skills, competences, gender, professions when analyzing from the individual perspective. West (2002) has created a famous model on team innovation, that either covers group task characteristics and external demands. Thus these models on creativity processes and team innovation promotion either sparkled the research on team composition, with a shift to an input from an internal perspective and ignoring the external context. Team personality composition refers to a combination of team members' individual characteristics, as reflected in team-level, and the personality composition of teams have been studied (Mathisen et al. 2008; Baer et al. 2008) in order to understand the better combinations to enhance creativity and innovation. The challenge is to create sufficient diversity within the team without threatening their shared view of their task and their ability to communicate and work effectively together (West 2002). Thus most of the research have focused on Big Five personality factors and even after the number of studies the results seem to be too broad for a proper composition of a team. Therefore, the new ideas and methodologies for the further research need to be presented. This will be attempted to do with a conceptual framework, accompanied by already existing and reliable measurements, which could provide a new look to the management of creative innovation teams and their performance from internal perspective, by correct composition of personalities.

\section{The Conceptual Framework for Analyzing the Performance of Creative Innovation Teams}

With the aim to take a new look on possible ways in performance management of creative innovation teams and special focus on internal team environment, specifically, personalities and their composition, the basis for the conceptual framework were developed. Examining team performance through the lens of input-process-output model, several measurements are encompassed in order to fully understand the links of these stages, input's influence on outputs, and to reveal the possible ways to manage them. Thus firstly, personality type with the team role of a person is aimed to be connected, secondly, their composition links with the success to manage team processes revealed, and finally, the relationship of team composition with the final outputs disclosed. The latter stage is expected to show the best compositions of the teams, given the presented outputs. Such framework could enable to manage the performance of creative innovation teams by setting the right composition of it. 
While many factors influence a team's performance, considerable attention has been given to the influence of team member diversity in terms of roles played in a team. The team role model made popular by Meredith Belbin in relation to management is one of the most widely used methods in practice and featured extensively in research on teams at work (Aritzeta et al. 2007; Partington \& Harris 1999). The eight role model was introduced and a team role was defined as a pattern of behavior characteristic of the way in which one team member interacts with another in order to facilitate the progress of the team as a whole. It was only after the initial research had been completed that the ninth team role, Specialist, emerged. The test developed is based on four key factors: intelligence, dominance, extroversion/introversion, stability/anxiety (Hipple et al. 2001; Figurska 2014). See the summary of team roles with the main characteristics enclosed in Table 1.

Table 1. Summary of Belbin's Team Roles

\begin{tabular}{|c|c|c|c|}
\hline Title & Characteristics & Upsides & Downsides \\
\hline \multicolumn{4}{|l|}{ Social } \\
\hline CO: Co-ordinator (Chairman) & $\begin{array}{l}\text { Clam, self-confident, } \\
\begin{array}{l}\text { controlled, tolerant, warm, } \\
\text { enthusiastic }\end{array}\end{array}$ & $\begin{array}{l}\text { Capacity for welcoming all } \\
\text { contributions and treating them } \\
\text { on their merits without } \\
\text { prejudice. Strong sense of } \\
\text { objectives }\end{array}$ & $\begin{array}{l}\text { No more than ordinary in terms } \\
\text { of intellect or creative ability }\end{array}$ \\
\hline TW: Team worker & $\begin{array}{l}\text { Socially oriented, rather mild, } \\
\text { sensitive, trusting, perceptive, } \\
\text { diplomatic }\end{array}$ & $\begin{array}{l}\text { An ability to respond to people } \\
\text { and situations. Promotes team } \\
\text { spirit }\end{array}$ & $\begin{array}{l}\text { Indecisive at moments of } \\
\text { conflict }\end{array}$ \\
\hline RI: Resource investigator & $\begin{array}{l}\begin{array}{l}\text { Extroverted, } \\
\text { enthusiastic, }\end{array} \\
\text { communicative }\end{array}$ & $\begin{array}{l}\text { Capacity for contacting people } \\
\text { and exploring anything new. } \\
\text { An ability to respond to } \\
\text { challenge }\end{array}$ & $\begin{array}{l}\text { Lacks inspiration and the } \\
\text { ability to motivate others }\end{array}$ \\
\hline \multicolumn{4}{|l|}{ Action } \\
\hline $\begin{array}{l}\text { IMP: Implementer (Company } \\
\text { worker) }\end{array}$ & $\begin{array}{l}\text { Conservative, } \\
\text { predictable }\end{array}$ & $\begin{array}{l}\text { Organizing ability, practical } \\
\text { common sense, hardworking, } \\
\text { self-disciplined }\end{array}$ & $\begin{array}{l}\text { Lack of flexibility, } \\
\text { unresponsiveness to unproven } \\
\text { ideas }\end{array}$ \\
\hline CF: Completer-finisher & $\begin{array}{lc}\begin{array}{l}\text { Painstaking, } \\
\text { conscientious, } \\
\text { consistent }\end{array} & \begin{array}{c}\text { orderly, } \\
\text { anxious, }\end{array} \\
\end{array}$ & $\begin{array}{l}\text { Capacity for follow-through, } \\
\text { perfectionism }\end{array}$ & $\begin{array}{l}\text { Tendency to worry about small } \\
\text { details. A reluctance to } \\
\text { 'let go' }\end{array}$ \\
\hline SH: Shaper & $\begin{array}{l}\text { Full of nervous energy, highly } \\
\text { strung, very high achievement } \\
\text { motivation, wants to win, } \\
\text { aggressive, extrovert }\end{array}$ & $\begin{array}{l}\text { Drive and readiness to } \\
\text { challenge inertia, } \\
\text { ineffectiveness, complacency } \\
\text { or self-deception }\end{array}$ & $\begin{array}{l}\text { Prone to provocation, irritation } \\
\text { and impatience }\end{array}$ \\
\hline \multicolumn{4}{|l|}{ Thinking } \\
\hline PL: Plant & $\begin{array}{l}\text { Innovative, } \begin{array}{l}\text { introverted, } \\
\text { independent, individualistic, } \\
\text { serious minded, unorthodox }\end{array} \\
\end{array}$ & $\begin{array}{l}\text { Genius imagination, intellect, } \\
\text { knowledge }\end{array}$ & $\begin{array}{l}\text { Up in the clouds, inclined to } \\
\text { disregard practical details or } \\
\text { protocol }\end{array}$ \\
\hline ME: Monitor evaluator & $\begin{array}{l}\text { Sober, unemotional, prudent, } \\
\text { detached, intelligent }\end{array}$ & $\begin{array}{ll}\text { Judgement, } & \text { discretion, } \\
\text { hardheadedness } & \\
\end{array}$ & $\begin{array}{l}\text { Lacks inspiration and the } \\
\text { ability to motivate others }\end{array}$ \\
\hline SP: Specialist & $\begin{array}{l}\text { Single-minded, self-starting, } \\
\text { dedicated. Provides knowledge } \\
\text { and skills in rare supply }\end{array}$ & $\begin{array}{l}\text { Single-minded, self-starting, } \\
\text { dedicated, provides knowledge } \\
\text { and skills in rare supply }\end{array}$ & $\begin{array}{l}\text { Contributes only on a narrow } \\
\text { front. Dwells on technicalities }\end{array}$ \\
\hline
\end{tabular}

Sources: Hipple et al. (2001), Belbin (2011), Belbin (2014), Aritzeta et al. (2007)

The second instrument is Myers-Briggs Type Indicator (MBTI), which is considered one of the oldest, most reliable and valid of the personality instruments. The purpose of the MBTI personality inventory, developed by Isabel Briggs Myers, is to make the theory of psychological types described by C. G. Jung understandable and useful in people's lives. It has been tested on millions of people, has proved to be useful tool in understanding human 
dynamics of both at work and social level, and effective tool in team building, communication and career exploitation (Von Stamm, 2008). The MBTI identifies four individual preferences (see Table 2): extroverts versus introverts (E vs. I), sensers versus intuitives ( $\mathrm{S}$ vs. N), thinkers versus feelers (T vs. F), judgers versus perceivers (J vs. P). The first three choices describe person's orientation towards life, the last choice a person's orientation to the outer world, resulting 16 possible types (Hipple et al. 2001). The summary of all MBTI types and their characteristics is provided in the Table 3.

Whilst this literature review has defined both MBTI and Belbin's Team Role model, to date no research has explicitly sought to establish the correlation between the two models. Due to the distinct characteristics portrayed by each team role, it may be reasonable to assume that the MBTI Belbin trait combinations can be supported in the research using the conceptual framework.

Table 2. Characteristics of eight MBTI types

\begin{tabular}{|c|c|}
\hline $\begin{array}{l}\text { Extroverts (E) } \\
\text { Are action-oriented and impulsive } \\
\text { Like to think out loud and tend to present rough drafts Outgoing } \\
\text { and social }\end{array}$ & $\begin{array}{l}\text { Introverts (I) } \\
\text { Enjoy privacy and quiet time } \\
\text { Tend to prefer fully developed ideas }\end{array}$ \\
\hline $\begin{array}{l}\text { Sensers (S) } \\
\text { Look at what is known and real } \\
\text { Rely on actual experience and proven results } \\
\text { Approach change slowly, carefully, incrementally, and critically }\end{array}$ & $\begin{array}{l}\text { Intuitives (N) } \\
\text { Perceive abstract things, meanings, relationships and possibilities } \\
\text { through insight } \\
\text { Like complexity, theoretical relationships and connections } \\
\text { between things } \\
\text { Able to see future possibilities, often unusual and abstract ones, } \\
\text { using imagination and theory }\end{array}$ \\
\hline $\begin{array}{l}\text { Thinkers }(\mathbf{T}) \\
\text { Use process of logical and impersonal decision making } \\
\text { Apply logical analysis to weigh facts and examine consequences } \\
\text { objectively }\end{array}$ & $\begin{array}{l}\text { Feelers }(\mathbf{F}) \\
\text { Arrive at conclusions through process of appreciation with a } \\
\text { system of subjective personal values and standards } \\
\text { Typically exhibits a warm understanding of people, compassion } \\
\text { empathy and the need for harmony }\end{array}$ \\
\hline $\begin{array}{l}\text { Judgers }(\mathbf{J}) \\
\text { Convergent, driving towards closure and results } \\
\text { Organisation, schedules, plans, and priorities are important }\end{array}$ & $\begin{array}{l}\text { Perceivers }(\mathbf{P}) \\
\text { Divergent, open, flexible and unconstrained } \\
\text { Tries to keep things open for new possibilities as long as possible } \\
\text { and does not want to miss anything }\end{array}$ \\
\hline
\end{tabular}

Source: Hipple et al. (2001)

Table 3. Summary of MBTI types

\begin{tabular}{|c|c|c|c|}
\hline Title & Characteristics & Strengths & Weaknesses \\
\hline \multicolumn{4}{|l|}{ Artisans } \\
\hline ESFP: The Performer & $\begin{array}{l}\text { Outgoing, friendly and } \\
\text { accepting. Exuberant lovers of } \\
\text { life and people. }\end{array}$ & $\begin{array}{l}\text { - Working with others } \\
\text { - Uses common sense } \\
\text { - Adaptable }\end{array}$ & $\begin{array}{l}\text { - Long-term commitments } \\
\text { - Does not take criticism well } \\
\text { - Takes things personally }\end{array}$ \\
\hline ESTP: The Promoter & $\begin{array}{l}\text { Takes a pragmatic approach. } \\
\text { Enjoys material comforts and } \\
\text { style. }\end{array}$ & $\begin{array}{l}\text { - Flexible and tolerant } \\
\text { - Focus on the present } \\
\text { - Learns by doing }\end{array}$ & $\begin{array}{l}\text { - Easily bored } \\
\text { • Unknowingly insensitive }\end{array}$ \\
\hline ISFP: The Composer & $\begin{array}{l}\text { Quiet, friendly, sensitive and } \\
\text { kind. Enjoys the present } \\
\text { moment. }\end{array}$ & $\begin{array}{l}\text { - Loyal and committed } \\
\text { - Laid back and adaptable } \\
\text { - Good listener }\end{array}$ & $\begin{array}{l}\text { - Shies away from conflict } \\
\text { - Hard to get to know } \\
\text { - Withdrawn }\end{array}$ \\
\hline ISTP: The Crafter & $\begin{array}{l}\text { Analyzes what makes things } \\
\text { work and can organize large } \\
\text { amounts of data. }\end{array}$ & $\begin{array}{l}\text { - Self-reliant } \\
\text { - Handles conflict well } \\
\text { - Efficient }\end{array}$ & $\begin{array}{l}\text { - Emotionally uncomfortable } \\
\text { Long-term planning }\end{array}$ \\
\hline
\end{tabular}




\begin{tabular}{|c|c|c|c|}
\hline \multicolumn{4}{|l|}{ Guardians } \\
\hline ESFJ: The Provider & $\begin{array}{l}\text { Warmhearted, conscientious } \\
\text { and cooperative. Want } \\
\text { harmony in life. }\end{array}$ & $\begin{array}{l}\text { - Focus on other's needs } \\
\text { - Money management } \\
\text { - Honors commitments }\end{array}$ & $\begin{array}{l}\text { - Dislikes change } \\
\text { - Takes blame for others } \\
\text { - Trouble with conflict }\end{array}$ \\
\hline ESTJ: The Supervisor & $\begin{array}{l}\text { Practical, realistic and } \\
\text { matterof-fact. Clear set of } \\
\text { logical standards. }\end{array}$ & $\begin{array}{l}\text { - Loyal and committed } \\
\text { - Social and enthusiastic } \\
\text { - Born leader }\end{array}$ & $\begin{array}{l}\text { - Expressing feelings } \\
\text { - Can be blunt and sensitive } \\
\text { - Like to always be right }\end{array}$ \\
\hline ISFJ: The Protector & $\begin{array}{lrr}\text { Quiet, friendly } & \text { and } \\
\text { responsible. Notice } & \text { and } \\
\text { remember specifics } & \text { about } \\
\text { people they care about. } & \end{array}$ & $\begin{array}{l}\text { - Good listener } \\
\text { - Eager to serve } \\
\text { - Great organization }\end{array}$ & $\begin{array}{l}\text { - Neglect own needs } \\
\text { - Dislikes change } \\
\text { - Takes criticism personally }\end{array}$ \\
\hline ISTJ: The Inspector & $\begin{array}{l}\text { Quiet, serious and very } \\
\text { responsible. Value traditions } \\
\text { and loyalty. }\end{array}$ & $\begin{array}{l}\text { - Orderly and organized } \\
\text { - Handles criticism well } \\
\text { - Good listener }\end{array}$ & $\begin{array}{l}\text { - Too rigid } \\
\text { - Needs to be right } \\
\text { - Not in tune with feelings }\end{array}$ \\
\hline \multicolumn{4}{|l|}{ Idealists } \\
\hline ENFJ: The Teacher & $\begin{array}{l}\text { Warm, empathetic, and } \\
\text { responsible. Finds potential in } \\
\text { everyone and provides } \\
\text { inspiring leadership. }\end{array}$ & $\begin{array}{l}\text { - Communication } \\
\text { - Affectionate and Loyal } \\
\text { - Honors commitments }\end{array}$ & $\begin{array}{l}\text { - Harbors hurt feelings } \\
\text { - Tendency to manipulate } \\
\text { - Tendency to smother }\end{array}$ \\
\hline ENFP: The Champion & $\begin{array}{l}\text { Warmly enthusiastic and } \\
\text { imaginative. Spontaneous and } \\
\text { flexible and can improvise } \\
\text { confidently. }\end{array}$ & $\begin{array}{l}\text { - Fun and optimistic } \\
\text { - Read others well } \\
\text { - Communication }\end{array}$ & $\begin{array}{l}\text { - Trouble with conflict } \\
\text { - Can be manipulative } \\
\text { - Easily bored }\end{array}$ \\
\hline INFJ: The Counselor & $\begin{array}{l}\text { Seek meaning in all things. } \\
\text { Want to understand what } \\
\text { motivates people. }\end{array}$ & $\begin{array}{l}\text { - Good listener } \\
\text { - Communication } \\
\text { - Insightful } \\
\end{array}$ & $\begin{array}{l}\text { - Trouble with conflict } \\
\text { - Can be manipulative } \\
\text { - Easily bored }\end{array}$ \\
\hline INFP: The Healer & $\begin{array}{l}\text { Seek to understand people and } \\
\text { help fulfill their potential. } \\
\text { Curious and quick to see } \\
\text { possibilities. }\end{array}$ & $\begin{array}{l}\text { - Loyal } \\
\text { - Loving and caring } \\
\text { - Reading other's feelings }\end{array}$ & $\begin{array}{l}\text { - Reacts emotionally } \\
\text { - Extreme dislike of criticism } \\
\text { - Blames themselves }\end{array}$ \\
\hline \multicolumn{4}{|l|}{ Rationalists } \\
\hline ENTJ: The Field Marshall & $\begin{array}{l}\text { Frank, decisive, and notices } \\
\text { inefficiencies. Enjoys } \\
\text { expanding knowledge and } \\
\text { sharing it with others. }\end{array}$ & $\begin{array}{l}\text { - Excellent with money } \\
\text { - Takes criticism well } \\
\text { - Goal setting }\end{array}$ & $\begin{array}{l}\text { - Controlling and intimidating } \\
\text { - Appears angry } \\
\text { - Impulsive }\end{array}$ \\
\hline ENTP: The Inventor & $\begin{array}{l}\text { Quick, alert and outspoken. } \\
\text { Resourceful in solving new } \\
\text { and challenging problems. }\end{array}$ & $\begin{array}{l}\text { - Communication } \\
\text { - Laid back } \\
\text { - Generating ideas }\end{array}$ & $\begin{array}{l}\text { - Poor follow-up skills } \\
\text { - Easily bored } \\
\text { - Argumentative }\end{array}$ \\
\hline INTJ: The Mastermind & $\begin{array}{l}\text { Strong drive for implementing } \\
\text { their ideas and achieving their } \\
\text { goals. }\end{array}$ & $\begin{array}{l}\text { - Highly intelligent } \\
\text { - Honors commitments } \\
\text { - Independent } \\
\end{array}$ & $\begin{array}{l}\text { - Unwilling to take blame } \\
\text { - Arrogant } \\
\text { - Intensive }\end{array}$ \\
\hline INTP: The Architect & $\begin{array}{l}\text { Seek to develop logical } \\
\text { explanations for everything } \\
\text { that interests them. Quiet, } \\
\text { contained and analytical. }\end{array}$ & $\begin{array}{l}\text { - Laid back } \\
\text { - Not demanding } \\
\text { - Imaginative and creative }\end{array}$ & $\begin{array}{l}\text { - Explosive } \\
\text { - Distrusting of others } \\
\text { - Critical of others }\end{array}$ \\
\hline
\end{tabular}

Sources: Briggs Myers \& Myers (1980), The Myers \& Briggs Foundation (2015)

After the combination of MBTI and team role presented by each individual in the team as an input, the process and output measurements need to be defined. Considering the literature on team management, particularly West's (2002) model on team innovation and Thaiman's (2003) enclosed metrics and influencers of innovative performance within innovative teams, the variables measuring team characteristics and team output characteristics were excluded. The initial conceptual framework for analyzing the performance of creative innovation teams is provided in Figure 1. This framework will be tested in the further research. 


\begin{tabular}{|c|c|c|}
\hline $\begin{array}{l}\text { Individual } \\
\text { characteristics }\end{array}$ & $\begin{array}{l}\text { Team } \\
\text { characteristics }\end{array}$ & $\begin{array}{l}\text { Team output } \\
\text { characteristics }\end{array}$ \\
\hline $\begin{array}{l}\text { - Myers Briggs personality type } \\
\text { - Belbin's team role }\end{array}$ & $\begin{array}{l}\text { - Goals } \\
\text { - Roles and functions } \\
\text { - Recognition } \\
\text { - Opportunities for development } \\
\text { - Communication } \\
\text { - Conflicts } \\
\text { - Trust } \\
\text { - Leadership }\end{array}$ & $\begin{array}{l}\text { - Time management } \\
\text { - Constant creation of new ideas } \\
\text { - High value added projects } \\
\text { - Appropriate number of generated } \\
\text { ideas } \\
\text { - Clear roles and functions } \\
\text { - Ability to accept and say goodbye to } \\
\text { team members } \\
\text { - Recognition of the mistakes } \\
\text { - Constant learning }\end{array}$ \\
\hline
\end{tabular}

Fig. 1. Conceptual framework for analyzing the performance of creative innovation teams

\section{Method}

The nature of the investigating topic determined the research to be entirely quantitative. In order to fulfil the objective to test the framework, creative innovation teams as unit of analysis were selected. Since it is a pivot research, these were the student teams. The sample consisted of 39 undergraduate students (16 male, 23 female) from Technology Entrepreneurship course. Participants were not initially acquainted with one another and later were randomly assigned to the teams. 10 teams were composed with the size range from 2 to 6 members.

Before working on the tasks, participants completed two web-based surveys - Myers-Briggs Type Indicator instrument and Belbin Self-Perception Inventory. During the course of 4 months these teams were working with the aim to create an innovative idea and a business plan for its implementation. In the last seminar, participants were asked to complete a questionnaire and rate the team processes and team output. The latter questionnaire was developed based on the variables indicated in the conceptual model, where the participants rated the team characteristics and team output characteristics answering the questions with a Leiter scale. Following the chosen tools for MBTI and Belbin's team role, which are based on questionnaires, and a new questionnaire developed, the survey research is set to answer the research questions. Thus to test the framework data collection involved 3 questionnaires. As the tools for personality type and team role identification are already developed, in this study the relationships of variables (team composition and innovation output) are the most important to understand.

Statistical analysis was used to find the linkages between MBTI type and Belbin's team role, team composition and team processes evaluations, team composition and evaluations of the outputs. The correct sample should enable to find the correlations and relationships between the variables in the future research. This would enable to conceptualize the model that would define which combination of personalities and roles needs to be present within the team for innovation as an outcome.

\section{Results}

Totally 39 students participated in the pilot research. Belbin's team roles test disclosed that the most common role is of Implementer and Resource investigator, each accounting for 20,5\% (8 persons) of the total respondents. The third mostly observed role was of Team worker (17,9\%, 7 persons). 12,8\% (5) were identified as Monitor evaluators, $10,3 \%$ (4) - Co-ordinators, $7,7 \%$ (3) - Completers-finishers. The most rare were Plants $(5,1 \%, 2$ persons) and Shapers with Specialists (2,6\%, 1 person each). Thus all 9 possible team roles were found in the students group.

However, Myers Briggs test identified only 10 from 16 MBTI types and relatively low number of Introverts. Large number of students were possessing Judger's characteristics, what reveals their orientation with an outer world being more strict and organized. Moreover, even 38,5\% (15 people) were found to be ENTJ type. The other two 
most commonly found types were ENFJ and ESFJ, each accounting of 17,9\% (7). Whilst only 5,1\% (2) were ENFP, ESTJ or INTP, and 2,6\% (1) - ESFP, ESTP, ISFJ or ISTJ. ENTP, INTJ, INFP, INFJ, ISFP and ISTP were not identified in the student group.

As can be seen in Annex 1, MBTI type and Team role crosstabulation was made to reveal the underpinnings between the personality types and the roles in the team taken. Due to the relatively small sample, no reasonable findings can be grounded. Nevertheless, 5 ENTJ types took the role of Implementer, which is 33,3\% within MBTI type and $62,5 \%$ within team role, and 4 - the role of Monitor evaluator, accounting for 26,7\% within MBTI type and even $80 \%$ within the role. Given the characteristics of knowledge sharing and controlling ENTJ, the most common team roles identified are not surprising. While Team workers were commonly found to be ENFJ type people, accounting 42,9\% within both, MBTI type and team role. Again, this finding can be grounded by similarities of characteristics - social, responsible and empathetic mode of ENFJ type and Team worker. These primary insights and the obvious connections of characteristics of MBTI type and team role taken that can be seen even from this small sample of students suggests that more accurate and reasonable findings can be seen using a much bigger sample. Therefore, the idea of possible links between Myers Briggs and Belbin models can be wellgrounded enclosing the correlations between types and roles in the future research.

The analysis of team compositions considering number of the people, MBTI types, team roles and their combination within a team, enclosed the cases to be very diverse (see Annex 2). Out of 11 teams, the number of people in the team varied from 2 to 6. Moreover, the repetition of MBTI types or team roles within teams was seen, with the cases, where all the team members were possessing the same MBTI type (e.g., all members of ENTJ type in Gods of cards or Thermocolor) or team roles (e.g., Team workers in Išmanioji). However, teams with a mix of personality types (e.g., E-apyrankè, E-system, LMG) or team roles ( e.g., Daily products, Eapyrankè, Esystem, Gudd, Thermocolor) were formed as well. Finally, two teams with different MBTI types and roles was observed (e.g., E-apyrankè, E-system).

Considering the process of a team work, expressed through evaluation of team characteristics, some teams had shown better results than the other (see Annex 3). The best team characteristics were achieved by two Team workers, ENFJ and ENTJ personalities (i.e., Išmanioji), and a team of four ENTJ personalities, with the roles of Implementer, Team worker and two Monitor evaluators (i.e., Gods of cards). Whereas another team of two ENTJ personalities, Implementer and Specialist (i.e., Thermocolor), did not show outstanding evaluation of team characteristics. As well as the team of three ENFJ type personalities, representing Plant, Resource investigator and Team worker (i.e., Daily products). These results are surprising, as the latter two teams had mixed team roles, which initially gives the assumption of combination to be right for a project. The same can be said about the team with the worst evaluation of team characteristics (i.e., Gudd), that had a proper mix of team roles. Nevertheless, in this team no social role was presented and that might be a reason of poor processes inside a team. Furthermore, no connections with the composition of a complete mix of MBTI types and team roles in a team (as presented in Eapyrankè and E-System) and team characteristics can be noticed. The same applies for the case of a particular team role or the combination of them that would influence the results of processes within a team. No effect if the team is small (e.g., 2 people) or large (e.g., 6 people) can be noted either. At least these are the conclusions of a small sample with no correlations available to count.

It is important to notice, that the evaluations of output characteristics as an average were higher than the evaluation of team characteristics in most of the cases (see Annex 4). Only one team showed significantly lower results considering the output even though evaluation of the process was relatively strong (i.e., Thermocolor). The closer look inside this case reveals the team inability to constantly create new ideas, manage time, define the clear roles and functions within a team and, finally, to create a high value added idea. This is the result of two rationalists ENTJ type personalities, with the roles of Implementer and Specialist, which represents particularly conservative, disciplined and narrow thinking people. Furthermore, the other team with low results in the output evaluation is combined of two ENTJ, one ESFJ and ENFJ type of personalities, that represented a mix of team roles Implementer, Plant, Completer-finisher, Monitor evaluator (i.e., Gudd), which was either mentioned considering 
poor team characteristics. Analysing the personalities of the team mentioned, ESFJ and ENFJ can be seen as very soft and kind types of people, who nevertheless were strengthened with a coordination of ENTJ. Moreover, this team had a construct of two action and two thinking team roles, what logically suggests the assumption of enabling the team to deliver stronger outputs. However, the highest evaluation of the outputs was presented in three teams that either showed the best results of the processes within a team (i.e., Išmanioji, Gods of cards, E-apyrankè). Two Team workers, ENFJ and ENTJ personalities (i.e., Išmanioji) showed the ability not only to run processes within a team, but either to deliver the outputs. The same implies to the team possessing the same ENTJ type by all members (i.e., Gods of cards), representing such team roles as Implementer, Monitor evaluator (2 people) and Team worker. It is important to notice that the composition of the team consists of social, action and thinking roles. The third team that got strong evaluations in outputs was combined by the people with different MBTI types and team roles (i.e., E-apyrankè). ENTJ, ENFJ and ESFJ represented Resource investigator, Team worker and Coordinator respectively. The MBTI types of this team were the same as in the poorest performing team (i.e., Gudd). Thus it points to the other factors that determined the success. Taking into account team roles, the Team worker was the role mostly detected in the teams presenting the best results. Nevertheless, the Team worker can either be found in the ones performing poorly. The complete mix of MBTI types and team roles in this team cannot also be considered as the factor of high outcomes, because the other team that either represents a mix (i.e., E-System) haven't showed good results neither in team processes, neither in the outcomes. Furthermore, again no effect of a team size was noted. Therefore the deeper analysis to understand the relations of team composition and its' outputs is needed.

Nevertheless, it is important to underline that all the teams evaluated high in outputs were able to constantly create new ideas, to generate an appropriate number of them and, finally, to present a high value added project, what shows the ability to spark the creativity and turn the generated ideas out to an innovation. These are the complex of variables to understand the creative innovation team's performance.

\section{Conclusions}

With the aim to study the relationships of team composition and innovation output conceptual framework for analyzing the performance of creative innovation teams was provided. Such framework invites for a discussion taking a new look to possible ways of innovative performance management, focusing on internal team environment, specifically, personalities and their composition, as the basis for innovative outcomes. Examining team performance through the lens of input-process-output model, MBTI and Belbin's team role instruments are used, as well as variables to measure the management of the processes within a team and the final outcomes. Due to the distinct characteristics portrayed by each team role, it is suggested that the MBTI Belbin trait combinations can be supported in the research. Moreover, the framework is expected to show the best compositions of the teams, given the presented outputs and enabling to manage the performance of creative innovation teams by setting the right composition of personalities and roles within the team. The initial research with student teams proved that the expected linkages can be found even in a relatively small sample and the framework with a bigger sample should be tested. The correct sample should enable to find the correlations and relationships between the variables in the future research. The major challenge is correct data analysis in order to come up with reliable theory - model. In order to achieve this the methodological and analytical means to quantify relationships between individual, team and output parameters should be established. Personality and team role tests need to be administered, innovation results need to be surveyed and classified based on deep statistical analysis. Team compositions and the causal connection between personality and team role mix and innovation result needs to be modeled and conceptualized. Theory-testing research would be appropriate to prove or clarify the model.

\section{References}

Amabile, T. M. 1996. Creativity and Innovation in Organizations, Harvard Business School Background Note, January, $396-239$.

Amabile, T. M.; Barsade, S. G.; Mueller J. S.; Staw B. M. 2005. Affect and creativity at work, Administrative Science Quarterly, 50: 637403. 
Aritzeta, A.; Swailes, S.; Senior, B. 2007. Belbin's Team Role Model: Development, Validity and Applications for Team Building, Journal of Management Studies, 44 (1): 96-118.

Baer, M.; Oldham, G. R.; Costa Jacobson, G.; Hollingshead, A. B. 2008. The Personality Composition of Teams and Creativity: The Moderating Role of Team Creative Confidence, Journal of Creative Behavior, 42(4): 255-282.

Belbin. 2011. Team Role Summary Descriptions. Available on the Internet: 〈www.belbin.com〉.

Belbin. 2014. Method, Reliability \& Validity, Statistics \& Research: A Comprehensive Review of Belbin Team Roles. Available on the Internet: 〈http://www.belbin.com/content/page/5596/BELBIN(uk)-2014-A\%20Comprehensive\%20Review.pdf〉.

Borghini, S. 2005. Organizational creativity: breaking equilibrium and order to innovate, Journal of Knowledge Management, 9(4): 1933.

Briggs Myers, I.; Myers, P. 1980. Gifts differing: understanding personality type. CA: Davies Black Publishing.

Figurska, I. 2014. Sustainable entrepreneurship: localization, acquiring and use of knowledge sources in competitive organization, Entrepreneurship and Sustainability Issues 1(4): 210-222. DOI: http://dx.doi.org/10.9770/jesi.2014.1.4(3)

Ford, C. M. 1996. A theory of individual creative action in multiple social domains, The Academy of Management Review, 21 (4): 111242.

Hipple, J.; Harde, D.; Wilson, S. A.; Michalski, J. 2001. Can corporate innovation champions survive? Chemical Innovation, November, $14-22$.

Katzenbach, J. R.; Smith, K. 1993. The discipline of teams, Harvard Business Review, March-April, 11-20.

Klijn, M.; Tomic, W. 2010. A review of creativity within organizations from a psychological perspective, Journal of Management Development, 29(4): 322-343.

Mathisen, G. E.; Martinsen, O.; Einarsen, S. 2008. The Relationship between Creative Personality Composition, Innovative Team Climate, and Team Innovativeness: An input - Process - Output Perspective, Journal of Creative Behavior, 42(1): 13-31.

Partington, D.; Harris, H. 1999. Team role balance and team performance: an empirical study, The Journal of Management Development, 18(8): 695-705.

The Myers \& Briggs Foundation, 2015. MBTI Personality Type. Available on the Internet: 〈www.myersbrigs.org>.

Thaiman, H. J. 2003. Managing innovative R\&D teams, $R \&$ D Management, 33(3): 297-311.

Von Stamm, B. 2008. Managing Innovation, Design and Creativity. Chichester: John Willey \& Sons.

West, M. A. 2002. Sparkling Fountains or Stagnant Ponds: An Integrative Model of Creativity and Innovation in Work Groups, Applied Psychology: An International Review, 51(3): 355-424.

Woodman, R. W.; Schoenfeldt, L. F. 1989. Individual differences in creativity: an internationalist perspective, in Handbook of Creativity. New York, NY: Plenum Press, 77-91.

Vytaute DLUGOBORSKYTE is a PhD in Management student with the research topic on Managing Creative Innovation Teams in R\&D and Technology Intensive Organizations at Kaunas University of Technology. She is already noted as a young researcher in Lithuania and has received The Research Council's of Lithuania scholarship, Lithuanian Academy of Sciences citation for a scientific work in 2014, Ministry's of Economy of the Republic of Lithuania award, Lithuanian Science and Engineering Societies Association's award. She is currently working as a Research associate at GLORAD - Research Center for Global R\&D Management concentrating on creativity and innovation. Her international experience gained while studying in Politecnico di Milano during PhD studies and in University of Bologna in Master studies. Research interests: creative innovation teams, creativity management, innovation management, R\&D and technology intensive enterprises. 
Vaiva NORVILAITE is a Master in Strategic leadership at Kaunas University of Technology, Lithuania. Her Master thesis focused management of creative team performance.

Prof. Dr. Monika PETRAITE is a full Professor at the Department of Strategic Management, Kaunas University of Technology, Lithuania. The research focus is on innovation ecosystems, innovation management (networked, open innovation, new product, responsible innovation), knowledge intensive entrepreneurship, high tech business strategies (especially small globally born businesses), organizational innovation culture and dynamic capabilities for innovation. She is an author of more than 40 research papers, 10 textbooks, contributed as a member of highest level expert group to the EC DG for Research "The role of community research policy in the knowledge-based economy", is in the core-expert group advising the Lithuanian Ministry of Economy in Innovation policy design and implementation. 
Annex 1. MBTI type and team role crosstabulation

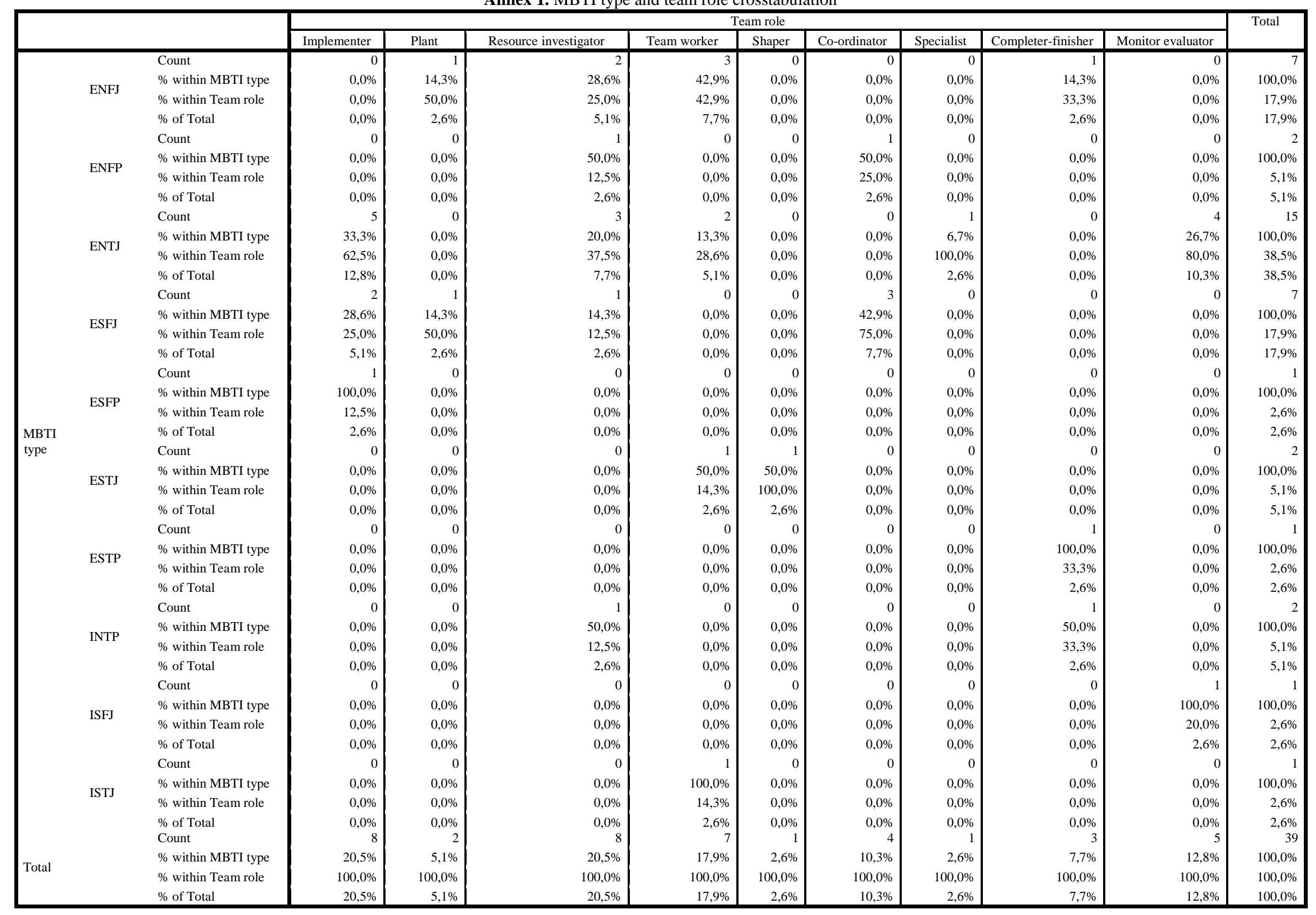


Annex 2. Team compositions

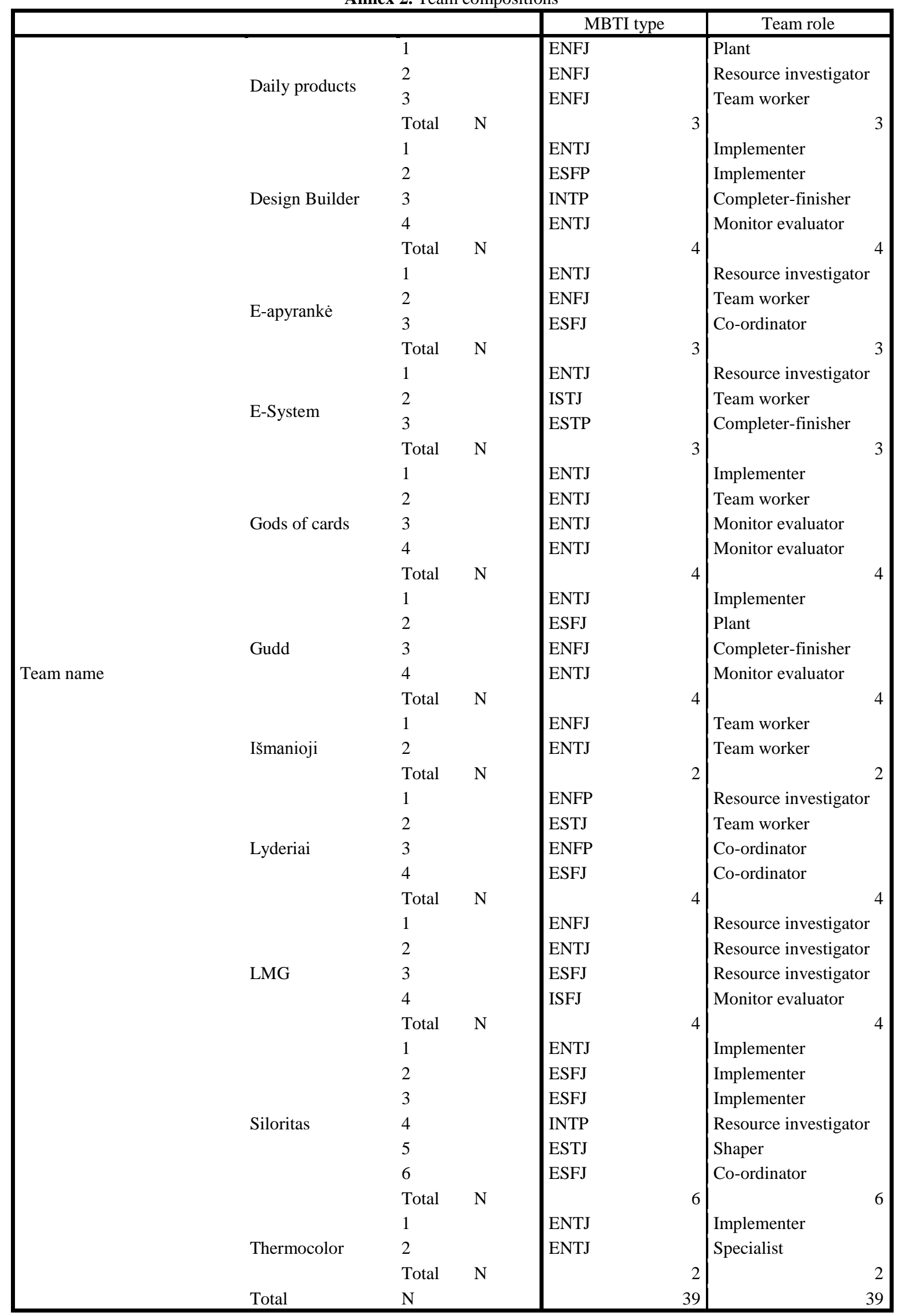


Annex 3. Evaluations of team characteristics

\begin{tabular}{|c|c|c|c|c|c|c|c|c|c|c|}
\hline \multirow[b]{2}{*}{ Team name } & & \multicolumn{9}{|c|}{ Team characteristics } \\
\hline & & Goals & $\begin{array}{l}\text { Roles and } \\
\text { functions }\end{array}$ & Recognition & $\begin{array}{l}\text { Opportunities } \\
\text { for } \\
\text { development }\end{array}$ & Communication & Conflicts & Trust & Leadership & Mean \\
\hline Daily products & Mean & 3,00 & 2,83 & 2,89 & 3,44 & 2,90 & 3,13 & 3,33 & 3,25 & 3,10 \\
\hline Design Builder & Mean & 3,00 & 2,71 & 3,17 & 3,22 & 3,43 & 2,70 & 3,13 & 2,94 & 3,04 \\
\hline E-apyrankė & Mean & 3,47 & 3,33 & 3,44 & 3,59 & 3,47 & 2,67 & 3,23 & 3,38 & 3,32 \\
\hline E-System & Mean & 3,33 & 2,78 & 3,33 & 3,15 & 2,80 & 2,40 & 3,03 & 3,04 & 2,98 \\
\hline Gods of cards & Mean & 3,65 & 3,08 & 3,75 & 3,61 & 3,65 & 2,70 & 3,50 & 3,22 & 3,40 \\
\hline Gudd & Mean & 2,60 & 2,58 & 2,50 & 2,75 & 2,93 & 3,05 & 2,93 & 3,03 & 2,80 \\
\hline Išmanioji & Mean & 3,50 & 3,17 & 4,00 & 3,94 & 3,60 & 2,80 & 3,35 & 3,69 & 3,51 \\
\hline Lyderiai & Mean & 3,60 & 3,17 & 3,50 & 3,36 & 3,20 & 2,70 & 3,43 & 3,31 & 3,28 \\
\hline LMG & Mean & 3,35 & 2,88 & 3,25 & 3,33 & 2,90 & 2,50 & 2,73 & 3,03 & 3,00 \\
\hline Siloritas & Mean & 3,10 & 3,31 & 3,22 & 3,17 & 3,27 & 2,73 & 3,15 & 3,23 & 3,15 \\
\hline Thermocolor & Mean & 3,00 & 3,50 & 3,00 & 3,67 & 3,35 & 2,80 & 2,95 & 3,50 & 3,22 \\
\hline Total & Mean & 3,23 & 3,02 & 3,26 & 3,33 & 3,22 & 2,74 & 3,16 & 3,20 & 3,14 \\
\hline
\end{tabular}

Annex 4. Evaluations of output characteristics

\begin{tabular}{|c|c|c|c|c|c|c|c|c|c|c|}
\hline \multirow[b]{2}{*}{ Team name } & & \multicolumn{9}{|c|}{ Output characteristics } \\
\hline & & $\begin{array}{l}\text { Time } \\
\text { management }\end{array}$ & $\begin{array}{l}\text { Constant } \\
\text { creation } \\
\text { of new } \\
\text { ideas }\end{array}$ & $\begin{array}{l}\text { High } \\
\text { value } \\
\text { added } \\
\text { projects }\end{array}$ & $\begin{array}{l}\text { Appropriate } \\
\text { number of } \\
\text { generated } \\
\text { ideas }\end{array}$ & $\begin{array}{l}\text { Clear } \\
\text { roles and } \\
\text { functions }\end{array}$ & $\begin{array}{l}\text { Ability } \\
\text { to say } \\
\text { goodbye } \\
\text { to a team } \\
\text { member }\end{array}$ & $\begin{array}{l}\text { Recognition } \\
\text { of the } \\
\text { mistakes }\end{array}$ & $\begin{array}{l}\text { Constant } \\
\text { learning }\end{array}$ & Mean \\
\hline $\begin{array}{l}\text { Daily products } \\
\text { Design }\end{array}$ & Mean & 3,00 & 3,00 & 3,00 & 3,67 & 3,50 & 2,67 & 3,50 & 3,17 & 3,19 \\
\hline Builder & Mean & 2,75 & 2,75 & 3,50 & 3,75 & 3,13 & 3,50 & 3,75 & 3,50 & 3,33 \\
\hline E-apyrankè & Mean & 3,33 & 3,67 & 3,33 & 3,00 & 3,42 & 3,33 & 3,67 & 3,50 & 3,41 \\
\hline E-System & Mean & 3,00 & 3,33 & 3,00 & 3,00 & 3,33 & 3,67 & 3,33 & 2,83 & 3,19 \\
\hline Gods of cards & Mean & 3,38 & 3,25 & 3,75 & 3,50 & 3,44 & 3,75 & 3,63 & 3,75 & 3,55 \\
\hline Gudd & Mean & 2,88 & 3,00 & 3,13 & 2,75 & 2,75 & 4,00 & 2,63 & 2,88 & 3,00 \\
\hline Išmanioji & Mean & 3,50 & 3,50 & 3,50 & 3,50 & 3,50 & 4,00 & 4,00 & 3,75 & 3,66 \\
\hline Lyderiai & Mean & 3,13 & 3,25 & 3,25 & 3,25 & 3,38 & 2,75 & 3,25 & 3,50 & 3,22 \\
\hline LMG & Mean & 2,75 & 3,25 & 3,25 & 3,75 & 3,13 & 2,50 & 2,75 & 3,25 & 3,08 \\
\hline Siloritas & Mean & 3,50 & 3,00 & 3,33 & 3,17 & 3,50 & 3,33 & 3,58 & 3,17 & 3,32 \\
\hline Thermocolor & Mean & 2,25 & 2,50 & 2,50 & 3,00 & 2,63 & 2,50 & 3,25 & 3,50 & 2,77 \\
\hline Total & Mean & 3,08 & 3,13 & 3,27 & 3,31 & 3,26 & 3,28 & 3,37 & 3,32 & 3,25 \\
\hline
\end{tabular}


This is an open access journal and all published articles are licensed under a

Creative Commons Attribution 4.0 International License

Copyright of Journal "Entrepreneurship and Sustainability Issues" (c) Entrepreneurship and Sustainability Center, All Rights Reserved 